Linguistik Terapan 18 (1) (2021): 33 - 39

Jurnal Linguistik Terapan Pascasarjana

Available online

http://jurnal.unimed.ac.id/2019/index.php/JLT-Unimed

\title{
NATURALIZATION IN TRANSLATION OF ENGLISH ACCOUNTING TERMS INTO INDONESIAN
}

\author{
Anita Basrah \\ Anni Holila Pulungan \\ Rahmad Husein \\ English Applied Linguistic Program \\ Postgraduate Program - Universitas Negeri Medan
}

Diterima Desember 2020; Disetujui Februari 2021; Dipublikasikan April 2021

\begin{abstract}
This research was to analyze the process of spelling adjustment of naturalization applied in translation of English accounting terms into Indonesian. The objective of the study was to find out the Process of spelling adjustment of naturalization were used by accounting terms. This research used a descriptive and qualitative method. The data of this study were words containing naturalization were taken from the translation of selected articles of accounting textbook, Accounting 2le (2008). The data were collected through documentary technique. The data analysis was concerned of the implementation of spelling adjustment of naturalization. The findings show that naturalization in EnglishIndonesian accounting terms occurred in three categories, namely grapheme, and syllabic adapatation (double consonant become single consonant and consonant inhibitory. The products of naturalization have followed the guidance yet several new adjustment standards need to be included to enrich the pattern of foreign term adoption. In addition, this study recommends that proess of absorption in the Indonesian guidance of term formation needs to be revisited in order to precisely classify how foreign terms spelling adjustment is made in the Indonesian language
\end{abstract}

Keywords: Naturalization, Translation Procedure, Accounting Terms, Spelling Adjustment

How to Cite: Basrah, Anita. (2021). Naturalization in Translation of English Accoounting Terms into Indonesian . Jurnal Linguistik Terapan-Pascasarjana Unimed. 18(1): 33 - 39

ISSN: 2407 - 7410 


\section{INTRODUCTION}

Translation procedures refer to the strategies applied by a translator in rendering the meaning from source language (SL) text to target language (TL) text. Procedures as proposed by Newmark (1988: 81) are the terms frequently used to refer to how linguistic units at micro level from sentences, clauses andthe smaller units of linguistics like phrases and words are translated (Pavlusova 2014). The term micro level here is used to compare to macro level which is a whole text summarized from the other Newmarks term i.e. translation methods. The application of translation procedures involving two languages with different system and culture leads to various interesting phenomena. In Indonesian context, translation has been accepted as one of the triggering factors of language development that is realized through the use of several translation procedures. The translation of a huge number of foreign terms into Indonesian results in several classifications showing different types of naturalization.

Naturalization as a translation procedure shows the adaptation of SL word to normal pronunciation, then to normal morphology of TL (Newmark 1988: 82). This means that naturalization focuses on the adaptation of form as the result of translation activity, which is automatically followed by the transfer of meaning. The adaptation of form may be realized in spelling adjustments that can be thoroughly observed by identifying the changes in both the phonological systems. The adjustment of spelling is closely related to phonological translation showing the adjustment of written system from the SL to the TL. Meanwhile, the spelling adjustment can be seen from how the terms are written in accordance with the spelling standards determined in the target language

The development of terms in science especially in accounting field grow rapidly, unfortunately it is only in English version. It makes many written works that were used Indonesian language in relation to accounting use many foreign terms (English terms). Based on the reason above, it is very important to find Indonesian terms for every field. Since the limitation of the time, the writer only focuses on the accounting terms.

Before conducting the research, the preliminary analysis of the accounting terms was done to study the efficiency of data analysis . The sample preliminary study was presented as following : 


\begin{tabular}{ccc}
\hline $\begin{array}{c}\text { SL } \\
\text { (English) }\end{array}$ & TL & The Process of \\
(Indonesian) & $\begin{array}{c}\text { Spelling } \\
\text { adjustment }\end{array}$ \\
$\begin{array}{c}\text { Management } \\
\text { (p.258) }\end{array}$ & $\begin{array}{c}\text { Manajemen } \\
\text { (p.285) }\end{array}$ & $\begin{array}{c}\text { Consonant } \\
\text { Inhibitory }\end{array}$ \\
\hline
\end{tabular}

Based on data, The English naturalization word [Manageme-nt] in SL adapted into indoesian word [Manajeme-n] in TL. It can be analyze that there is adjustment of consonant cluster. The process of naturalization is the adjustment of consonant cluster that takes place through consonant inhibitory. The change from [Manageme-nt] to [Manajeme-n] demonstrates adaptations from consonant cluster $[\boldsymbol{n t}]$ to $[\boldsymbol{n}]$. At the final pronunciation deleted phoneme $[t]$ is seen in the TL word. The consonant clusters at the end of pasca vocal usually do not change and lost, even sometimes get addition. So, The terms that absorbed on this type of cluster usually the inhibition consonant is deleted. This adaptation shows the spelling adjustments which are done according to Indonesian systems of the term formation.

\section{A. Naturalization Theory}

One of the procedures used in translation is naturalization. It is applied to get the most appropriate translation result. Naturalization is done through adaptation of the sound and spelling. As Newmark (1988: 82) stated that this procedure succeeds transference and adapts the SL word first to the normal pronunciation, then to the normal morphology (wordforms) of the TL. The transfer of meaning is done by adjusting the pronunciation and spelling from source language into target language.

\section{B. Spelling Adjustment}

Sayogie (2009: 61) says that based on the level of its integration in the absorption of Bahasa Indonesia, it can be divided into three major categories. First, the element is no longer needed to change its spelling, such as trailer, audiogram, unit, etc. Second, the foreign elements that have not been fully absorbed into Bahasa Indonesia, like shuttle cock, real estate. These elements are used in Bahasa Indonesia context, but the pronunciation still follows foreign ways. Third, the foreign elements both of the pronunciation and writing rules were adapted into Bahasa Indonesia. 


\section{Grapheme}

Grapheme is the overall of letters or combination of letter that represent phonemes. Grapheme f represent fan, ph represent photo, and $g h$ represent cough is a grapheme with three variants or allograph. Soenjono Djarwowidjojo states that an ideal writing system is that the relationship between graphemes and phonemes that one-onone. It means each phoneme is represented by one grapheme with one variant. There are differences between phonemes and graphemes. If we talk about phonemes, we were talking about the sound; when we talk about the letter, it was graphemes.

In this language, a grapheme can be represented by several kinds of allograph or variant. For example, phoneme $/ \mathrm{k} /$, can be represented by eleven allograph: c-cash, cc- account, cch- bacchanal, ck- back, ch- character, cq- acquaint, cque- sacque, cubiscuit, k- keep, q- barbeque, and qu- liquor. Conversely, one grapheme can represent some phonemes. Grapheme <gh> can represent phoneme /f/, as in rough, /p/ as in hiccough, and /g/ as in ghost

D. Syllabic Adaptation

The adjustment is also found in syllables. It is called adjustment syllabic. This adjustment occurred because English syllable structure is different with the form of grammar in Bahasa Indonesia.

1. Double consonants become single consonant.

Bahasa Indonesia has no double consonant. Therefore, all the words or terms that have double consonant from source language are adapted into a single consonant in Bahasa Indonesia.

2. Consonant inhibitory

Most of consonant clusters pasca vocal in English terminated by the inhibition consonant beside of consonant shift and nasal. Otherwise, Bahasa Indonesia has no consonants cluster in the end of a word. In Bahasa Indonesia structure system; there are no consonant clusters moreover pasca vocal consonant clusters especially if the end of consonant that consonant clusters is dental inhibition consonant. If the terms that absorbed on this type of cluster usually the inhibition consonant is deleted. 


\section{METHODOLOGY}

Method of this study. Ary (1982) states that descriptive research studies are designed to obtain information concerning the current status of phenomena this method was related to this study because this study aimed at analyzing the process of spelling adjustment of naturalization in translation of English accounting terms into Indonesian. The data of the study are words containing naturalization in translation of English accounting terms into Indonesian. In consideration of accounting terms, this research analyzed an English book entitled Accounting 21e in original version that was published in 2005 and the Indonesian version entitled Pengantar Akuntansi 21 e translated by Aria Farahmita was published in 2008. The book used as the main source in this research. The book was divided into ten chapters. And the ten chapters that made up of accounting terms.

\section{FINDING AND DISCUSSION}

After analyzing the data, the researcher investigate that all process spelling adjustment of naturalization in translation of English accounting terms into Indonesian. The researcher found that there were three process of naturalization by Soenjono Djawidjojo (2005). They are; grapheme, and syllabic adapatation (double consonant become single consonant), and consonant inhibitory. It was investigate that all process of spelling adjustment of naturalization displayed in table below.

TABLE The Process of Spelling Adjustment of Naturalization

\begin{tabular}{|c|c|c|c|}
\hline No & The Processes & Data & $\begin{array}{c}\text { Percentages } \\
\%\end{array}$ \\
\hline & Grapheme & 61 & 76.25 \\
\hline 2. & $\begin{array}{l}\text { Syllabic Adaptation } \\
\text { ( Double consonants } \\
\text { become single } \\
\text { consonant) }\end{array}$ & 9 & 11.25 \\
\hline 3. & Consonant Inhibitory & 10 & 12.50 \\
\hline & Total & 80 & 100 \\
\hline
\end{tabular}


Based on the Table above, It can be seen that the highest percentage of the process in spelling adjustment of naturalization in translation of English accounting terms into Indonesian was used a Grapheme process it was 61 data with $76.25 \%$ and the second is Syllabic Adaptation (doubel consonant become single consonant) process it was 9 data with $11.25 \%$ and the last Consonant Inhibitory process it was 10 data with $12.50 \%$. in addition, the grapheme as the dominant the processes of naturalization. It indicates that English phonemes contained in the pure phonological system of Indonesian. And also that the researcher was combined the data from phonemes in adjustment of vowel, and adjustment of consonant and adjustment of affix. and the lowest percentage from this result was Syllabic Adaptation (doubel consonant become single consonant).

\section{CONCLUSIONS}

This study which were represented that there were three the processes of spelling adjustment of naturalizaton in translation of English accounting terms into Indonesian, namely: Graphemic syllabic adaptation (double consonants become single consonant) and consonant inhibitory. The grapheme as the dominant the processes of naturalization. It indicates that English phonemes contained in the pure phonological system of Indonesian. And also that the researcher was combined the data from phonemes in adjustment of vowel, and adjustment of consonant and adjustment of affix. and the lowest percentage from this result was Syllabic Adaptation (doubel consonant become single consonant). English phoneme does not have characteristics in common with Bahasa Indonesia phoneme; need some adjustments to get the nearest spelling form in accordance with phonological system of Bahasa Indonesia. The process of adaptation rather than elements of English had just occurred. This process was known long before the known of Bahasa Indonesia presence, when it was still known Malay language because the relationship with the English already established several centuries earlier.

Finally, in terms of spelling adjustment of naturalization in the translation of the English-Indonesian accounting terms has been done in accordance with the Indonesian rules determined in the Indonesian spelling standard. Several rules of spelling adjustment are applied perfectly in the translation. However, new adjustment standards must be considered whenever revision is made by the authority since several adjustments found in this study has not been covered in the guidance 


\section{REFERENCES}

Ary, Donald. (1982). Pengantar Penelitian dalam Pendidikan. (Terjemahan Arief Furchan). Surabaya: Usaha Nasional.

Djarwowidjojo,Soenjono.(2005). Psikolinguistik: Pengantar Pemahaman Bahasa Manusia. Jakarta: Yayasan Obor Indonesia

Newmark, P. (1988). A textbook of translation. London: Prentice Hall

PavlusovaŠÁ, I. (2014). Reverse naturalization in translation of a clockwork orange by A. Burgess. SKASE Journal of Translation and Interpretation [online], 7 (1) Available online <http://www.skase.sk/Volumes/JTI08/pdf_doc/05.pdf>. ISSN 1336-7811

Pusat Bahasa Departemen Pendidikan Nasional, (2007). Pedoman Umum Pembentukan Istilah. Jakarta: Kementrian Pendidikan Nasional

Sayogie, F. 2009. Teori dan Praktek Penerjemahan: Bahasa Inggris ke dalam Bahasa Indonesia. Tangerang: Pustaka Anak Negeri

Warren S . (2005) .Accounting 21 E. t he United States of America. ISBN: 0-324-18800-5 (Accounting, 21e)

Warren S. (2008). Pengantar Akuntansi Edisi 21 by Aria Farahmita into Indonesian, Salemba Empat ; Jakarta 